\title{
Decision making by health professionals during COVID-19: an integrative review
}

\author{
Tomada de decisões dos profissionais de saúde na COVID-19: revisão integrativa
}

Toma de decisiones de los profesionales de salud frente al COVID-19: revisión integrativa

\author{
Camila Oliveira Valente' \\ ORCID: 0000-0003-0754-488X \\ Fernanda Rios da Silva" \\ ORCID: 0000-0002-6584-6651 \\ Fernanda Carneiro Mussi"' \\ ORCID: 0000-0003-0692-5912 \\ Maria Ribeiro Lacerda" \\ ORCID: 0000-0002-5035-0434 \\ Kátia Santana Freitas' \\ ORCID: 0000-0002-0491-6759 \\ Darci de Oliveira Santa Rosa'"I \\ ORCID: 0000-0002-5651-2916
}

'Universidade Estadual de Feira de Santana. Feira de Santana, Bahia, Brazil.

"Universidade Federal do Paraná. Curitiba, Paraná, Brazil. "'Universidade Federal da Bahia. Salvador, Bahia, Brazil.

How to cite this article:

Valente CO, Silva FR, Mussi FC, Lacerda MR, Freitas KS, Santa Rosa DO. Decision making by health professionals during COVID-19: an integrative review. Rev Bras Enferm. 2022;75(Suppl 1):e20210067. https://doi.org/10.1590/0034-7167-2021-0067

Corresponding author:

Fernanda Rios da Silva

E-mail: enfafernandarios@hotmail.com

EDITOR IN CHIEF: Dulce Barbosa ASSOCIATE EDITOR: Hugo Fernandes

Submission: $08-13-2020$

Approval: 06-22-2021

\begin{abstract}
Objective: To analyze the scientific production on the decision making of health workers during the COVID-19 pandemic. Methods: Integrative review in the databases CINAHL, MEDLINE, Scopus, ScienceDirect, WoS, and BVS. Inclusion criteria: original articles available in full, in any language, related to the object investigated. Results: During this pandemic, health workers have been making decisions based on ethical/bioethical principles (utility, beneficence, non-maleficence, autonomy, justice, proportionality, flexibility, clinical prognosis, duration of the need, and fair health attention), values (solidarity, equality, equity, utilitarianism, relational autonomy, reliability, reciprocity, maximization of the benefits and resources, and prioritization of those in worse conditions), beliefs and personal motivation, protocols, directives, tools, algorithms, recommendations, and criteria. Final considerations: Decision making has never been so necessary as in this pandemic. This article is not a recipe for the professionals, since decision making is based on numerous factors. However, it provides them with a foundation that can be helpful in this difficult process.
\end{abstract}

Descriptors: Decision Making; Ethics; Health Personnel; Pandemics; Coronavirus Infections.

\section{RESUMO}

Objetivo: Analisar as produções científicas sobre a tomada de decisões dos profissionais de saúde na pandemia COVID-19. Métodos: Revisão integrativa nas bases CINAHL, MEDLINE, Scopus, ScienceDirect e WoS e na BVS. Critérios de inclusão: artigos originais disponíveis na íntegra, em qualquer idioma, relacionados ao objeto investigado. Resultados: Os profissionais de saúde nesta pandemia têm tomado decisões baseadas em princípios éticos/bioéticos (utilitarismo, beneficência, não maleficência, autonomia, justiça, proporcionalidade, flexibilidade, prognóstico clínico, duração de uma necessidade e atendimento justo), valores (solidariedade, igualdade, equidade, utilidade, autonomia relacional, confiança, reciprocidade, maximização dos benefícios dos recursos e priorização daqueles em pior situação), crenças e motivações pessoais, protocolos, diretrizes, ferramentas, algoritmos, recomendações e critérios. Considerações finais: A tomada de decisões nunca se fez tão necessária como nesta pandemia. Este artigo não fornece uma receita pronta aos profissionais, pois a tomada de decisões envolve múltiplos fatores, todavia apresenta várias bases capazes de auxiliá-los neste difícil processo.

Descritores: Tomada de Decisões; Ética; Pessoal de Saúde; Pandemias; Infecções por Coronavírus.

\section{RESUMEN}

Objetivo: Analizar producciones científicas sobre la toma de decisiones de profesionales de salud frente al COVID-19. Métodos: Revisión integrativa en las bases CINAHL, MEDLINE, Scopus, ScienceDirect y WoS y BVS. Criterios de inclusión: artículos originales disponibles integralmente, en cualquier idioma, relacionados al objeto investigado. Resultados: Profesionales de salud en esta pandemia toman decisiones basadas en principios éticos/bioéticos (utilitarismo, beneficencia, no maleficencia, autonomía, justicia, proporcionalidad, flexibilidad, pronóstico clínico, duración de una necesidad y atención justa), valores (solidaridad, igualdad, equidad, utilidad, autonomía relacional, confianza, reciprocidad, maximización de los beneficios de los recursos y priorización de aquellos en peor situación), creencias y motivaciones personales, protocolos, directrices, herramientas, algoritmos, recomendaciones y criterios. Consideraciones finales: La toma de decisiones nunca fue tan necesaria como en esta pandemia. Este artículo no proporciona una receta lista a profesionales, pues la toma de decisiones envuelve múltiplos factores, aún presenta varias bases capaces de auxiliarlos en este difícil proceso.

Descriptores: Toma de Decisiones; Ética; Personal de Salud; Pandemias; Infecciones por Coronavirus. 


\section{INTRODUCTION}

On March 11, 2020, the World Health Organization (WHO) declared that the outbreak of COVID-19, caused by the new coronavirus (SARS-CoV-2), was a Public Health Emergency of International Concern (PHEIC), characterizing it as a pandemic ${ }^{(1)}$. Most countries failed to recognize the threat of coronavirus at first and did not know how to deal with the situation ${ }^{(2)}$. There was insufficient knowledge about the means of transmission and about the behavior of asymptomatic people and its influence in the dissemination of SARS-CoV-2. This, coupled with the nonexistence of vaccines or specific therapeutic alternatives, was a challenge for researchers, health managers and governors in the search for non-pharmacological public health measures that could decelerate the spread of the virus ${ }^{(3)}$.

The WHO, seeking to give a direction to health practices, elaborated restrictive measures such as blockades, quarantines, and social isolation, as well as diagnostic measures, such as the testing suspected cases. They also took measures to screen for contacts and isolate people with suspected or confirmed cases of the disease. They made an attempt to contain the propagation of the virus ${ }^{(1,4)}$, minimizing morbimortality indexes and reducing the overload of health systems $s^{(1,4-6)}$.

The health professionals in the front lines of the struggle against COVID-19 started to have difficulties regarding decision making (DM). This is a process that involves logical and psychological actions, attitudes, factors, phenomena and values, as it seeks to select the most adequate alternative among those available to reach the objective selected ${ }^{(7)}$.

In this regard, since the pandemic crisis affected the offer of assistance in health due to an increased demand for attention and to the scarcity of resources, health professionals started to raise questions about how to proceed in these situations they had never experienced. These were problems hard to solve ${ }^{(8-9)}$, required fast $\mathrm{DM}$, and offered no space for in-depth reflection or the necessary planning ${ }^{(10-11)}$. This led to doubts, dilemmas, and ethical and moral conflicts.

Among the questions raised by the professionals, stand out: Is not providing vulnerable people with the adequate assistance an ethical infraction or a crime of denial of assistance? Since the morbimortality is higher among elders, should I prioritize younger patients to the detriment of older ones ${ }^{(12)}$ ? When attending two patients who need mechanical ventilation, if there is only one ventilator, which patient to choos $\mathrm{e}^{(11,13)}$ ? In the absence of adequate personal protective equipment (PPE), do I have the moral obligation and the professional duty to provide assistance ${ }^{(9,13)}$ ? How should patients be admitted to Intensive Care Units (ICUs) during a pandemic ${ }^{(11,14)}$ ? How to allocate scarce resources, such as ICU beds, ventilators, and medication? How is it possible to address end-of-life issues, including the non-resuscitation of the patient ${ }^{(15)}$ ? Are the decisions I make in my professional practice ethical ${ }^{(16)}$ ?

Considering the above, recommendations, DM models, protocols, guidance, and updated information have been continuously requested by professionals and offered by institutions and health systems, to make the DM process more transparent to society and bring safety to professionals and users of the health system. Therefore, this study provides a framework for the discussion and reflection about the decisions made by health professionals who work daily in the struggle against COVID-19 in several settings.

\section{OBJECTIVE}

To analyze the scientific production on the decision making of health workers during the COVID-19 pandemic.

\section{METHODS}

\section{Ethical aspects}

Due to the bibliographical nature of the research, it did not required evaluation by a Research Ethics Committee. However, the ethical aspects and the copyright of the works mentioned were considered.

\section{Type of study}

This is an integrative literature review, as it gathered and summarized the scientific knowledge produced about a certain area or phenomenon of interest through the search, evaluation, and synthesis of knowledge, contributing for the development of a practice based on scientific evidence ${ }^{(17)}$.

\section{Setting of the study}

This revision was developed at the moment when the COVID-19 pandemic was assuming an alarming proportion, the health systems were overloaded, and the worldwide mortality rate was high.

\section{Methodological procedures}

For the development of this study, the following stages were followed: 1) the research question was formulated using the PICo acronym; 2) sampling - inclusion and exclusion criteria were established, databases were screened and studies were selected; 3) data extraction - two tables were filled in with information about the works that formed the corpus of this work; 4) critical evaluation of works included - classification of evidence level $(E L) ; 5)$ analysis and synthesis of results - collection of information focused on the research question; and 6) presentation of the integrative revision ${ }^{(17)}$.

\section{Data collection and organization}

In this study, the PICo strategy was used to elaborate the guiding question $^{(18)}$ : (P) Population - health workers; (I) Phenomenon of Interest - decision making; and (Co) Context - a moment during the COVID-19 pandemic. As a result, the following research question was formed: How do health professionals make decisions during the COVID-19 pandemic?

To answer it, studies on the theme were surveyed. The terms selected for the search were validated in the Medical Subject Headings (Mesh/PubMed), with their respective synonyms found in the Health Sciences Descriptors (DeCS), considering those that fit the theme of the research better. The following electronic databases were consulted: Cumulative Index to Nursing and 
Allied Health Literature (CINAHL), Medical Literature Analysis and Retrieval System Online (MEDLINE), Scopus, ScienceDirect, Web of Science (WoS), and in the Virtual Health Library (Biblioteca Virtual em Saúde - BVS) portal. Associations between the descriptors, using the boolean operators $A N D$ and $O R$ were carried out in the databases and in the BVS portal, and the search strategies presented in Chart 1 were structured.

Chart 1 - Databases and portal consulted, as well as their respective search strategies

\begin{tabular}{|c|c|}
\hline Database/portal & Search strategies \\
\hline $\begin{array}{l}\text { CINAHL/ MEDLINE/ } \\
\text { WoS/ BVS portal }\end{array}$ & $\begin{array}{l}\text { "Decision Making" AND ("Health Personnel" OR } \\
\text { "Health Care Provider" OR "Health Care Providers" } \\
\text { OR "Healthcare Provider" OR "Healthcare } \\
\text { Providers" OR "Healthcare Worker" OR "Healthcare } \\
\text { Workers" OR "Personnel, Health" OR "Provider, } \\
\text { Health Care" OR "Provider, Healthcare" OR } \\
\text { "Providers, Health Care" OR "Providers, Healthcare) } \\
\text { AND ("Ethics" OR "Ethical Issue" OR "Ethical Issues" } \\
\text { OR "Ethics, Situational" OR "Issues, Ethical" OR } \\
\text { "Situational Ethics" OR "Bioethics" OR "Ethics, } \\
\text { Health Care" OR "Health Care Ethics") AND } \\
\text { ("Pandemics" OR "Coronavirus" OR "Covid-19"). }\end{array}$ \\
\hline $\begin{array}{l}\text { Scopus/ } \\
\text { ScienceDirect }\end{array}$ & $\begin{array}{l}\text { "Decision Making" AND ("Health Personnel" OR } \\
\text { "Healthcare Worker") AND ("Ethics" or "Bioethics) } \\
\text { and ("Pandemics" or "COVID-19"). }\end{array}$ \\
\hline
\end{tabular}

The criteria of inclusion were: original articles available in full, in any language, related to the object investigated. The criteria of exclusion were: revisions, experience reports, case studies, editorials, book chapters, abstracts from annals, articles found duplicate in the bases, studies whose design or objective were not made explicit and about the DM of professionals in management, research, or teaching. As a temporal framework, studies considered since the beginning of the COVID-19 were published until July 2020, the period in which the search took place in the bases and in the portal.

After the survey, the publications found were read in the following order: titles, abstracts, and text in full. In each stage, the works that were not in accordance with the inclusion criteria and/or did not answer the research question were excluded. Data selection, from its initial survey until the formation of the sample, was carried out by two of the six authors of the study, separately, following, thus, a double independent selection. Disagreements in the results were solved via consensus, and a third reviewer was unnecessary.

A table was formed including the following variables: title, authors, language, year of publication, journal, and database where the work is indexed. This contributed to compile and summarize the external information of each production selected. Later, a second table was formed with all internal information: title, method, main results and level of evidence (LE) ${ }^{(19)}$. The tables were organized by all authors in a process of continuous revision.

The articles included in the study were selected in accordance with the recommendations from the flowchart Preferred Reporting Items for Systematic reviews and Meta-Analyses (PRISMA), which is considered to be useful in many different types of revision ${ }^{(20)}$. Through its use, it became easy to show the process of selection of articles (Figure 1).

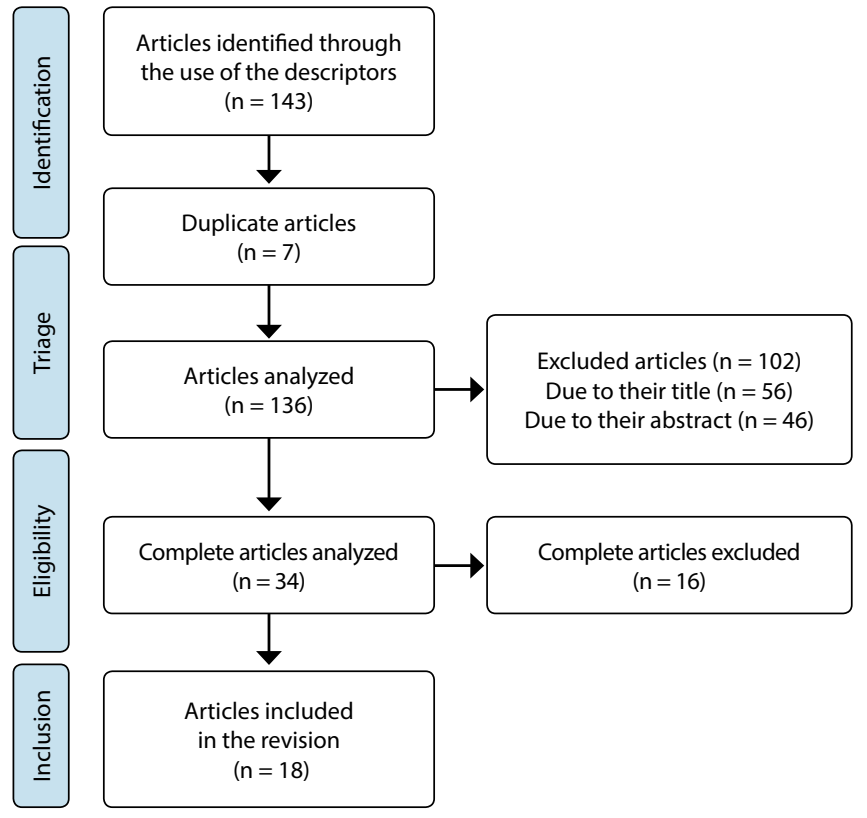

Figure 1 - Flowchart of the identification and selection of studies included in the review

\section{RESULTS}

The sample was formed by 18 articles. Reflection articles were the most common design $(94.44 \%)^{(2,4-6,8-11,13-16,21-25)}$, followed by descriptive qualitative studies $(5.56 \%)^{(26)}$. Most articles were published in English (94.74\%) $)^{(2,4-6,9-11,13-15,24-26)}$, in journals from the medical $(55.60 \%)^{(2,4,8,11,13-16,22,25)}$, ethical $(33.30 \%)^{(5-6,10,21,24,26)}$, and public health fields $(11.10 \%)^{(9,23)}$. The BVS was the portal with the highest number of articles $(73.68 \%)^{(2,4-5,8,10,13-14,16,21,26)}$, followed by ScienceDirect $(15.79 \%)^{(9,15,25)}$, and MEDLINE $(10.53 \%)^{(6,11)}$.

Eight studies were carried out in North America (seven in the United States of America and one in Canada) $)^{(2,8-9,13,15-16,23,25)}$, seven in Europe (two in Spain, two in Italy, two in the United Kingdom, and one in Belgium) ${ }^{(5,10-11,14,22,24,26)}$, two in Asia (one in Israel and one in Nepal) ${ }^{(4,6)}$, and one involved researchers from both Europe and $\mathrm{Asia}^{(21)}$. There were no studies in South America.

Regarding the professionals analyzed, 11 articles referred to health workers in general ${ }^{(2,4-5,11,14-16,21-23,26)}$; five, to physicians $^{(6,8,13,24-25)}$; one to a bioethicist ${ }^{(10)}$; and one, to nurses ${ }^{(9)}$. Most authors were physicians working on research or teaching (84.22\%), followed by researchers connected to departments or institutions of nursing (5.26\%), bioethics (5.26\%), and philosophy (5.26\%). Regarding ethics, some authors were associated with research ethics committees or ethical communities (31.58\%). Regarding the context, they addressed DM in intensive care $(44.45 \%)^{(4,6,8-9,14,21-22,24)}$, as well as in outpatient $(33.34 \%)^{(2,5,15,23,25-26)}$, surgical $(11.11 \%)^{(11,16)}$, cardiological $(5.55 \%)^{(13)}$, and emergency care $(5.55 \%)^{(10)}$.

Regarding the $\mathrm{EL}^{(19)}, 55.6 \%^{(2,4-6,8-9,11,16,23,26)}$ of studies were classified as level VI (evidences from descriptive or qualitative studies), while $44.4 \%{ }^{(10,13-15,21-22,24-25)}$ as level VII (evidences from the opinion of authorities and/or reports from specialist committees). The articles that form the sample are characterized in Chart 2. 
Chart 2 - Characterization of the studies selected for the revision according to the references of the article selected, year of publication and country, design, and main results, Salvador, Bahia, Brazil, 2020

\begin{tabular}{|c|c|c|c|}
\hline Reference & $\begin{array}{c}\text { Year } \\
\text { Country }\end{array}$ & $\begin{array}{l}\text { Design } \\
\text { mento }\end{array}$ & Main results \\
\hline (2) & $\begin{array}{l}2020 \\
\text { USA }\end{array}$ & $\begin{array}{l}\text { Theoretical } \\
\text { reflection }\end{array}$ & $\begin{array}{l}\text { In addition to ethics for DM, professionals must consider religious beliefs, motivations, and (personal } \\
\text { and professional) values in clinical practice. The study addresses the need to facilitate and dynamize } \\
\text { the flow of relevant, transparent, and consistent information about the new coronavirus, for } \\
\text { professional training and better DM, and for the population to develop a reasonable risk evaluation } \\
\text { in conditions of uncertainty. When there are two patients and one resource, a relocation must take } \\
\text { place, and the resource should be offered to the patient with a better prognosis, according to the } \\
\text { principle of distributive justice (scarce resources distributed fairly, to those who need most). In these } \\
\text { cases, health workers must remain neutral, impartial, and follow the utilitarian principle (the greatest } \\
\text { good for the greatest number of people). }\end{array}$ \\
\hline (4) & $\begin{array}{l}2020 \\
\text { Nepal }\end{array}$ & $\begin{array}{l}\text { Theoretical } \\
\text { reflection }\end{array}$ & $\begin{array}{l}\text { Professional DM must be based on the principles: autonomy (the social wellbeing must be above the } \\
\text { individual wellbeing); non-maleficence (the poor, marginalized, and those who need treatment are } \\
\text { those who suffer the most with isolation, so there must be a mechanism for the social support of the } \\
\text { most vulnerable); beneficence (triage and isolation of cases that are suspicious according with the } \\
\text { social wellbeing); and justice (those who are more likely to survive have priority in treatment). }\end{array}$ \\
\hline (5) & $\begin{array}{l}2020 \\
\text { United } \\
\text { Kingdom }\end{array}$ & $\begin{array}{l}\text { Theoretical } \\
\text { reflection }\end{array}$ & $\begin{array}{l}\text { Central and ethical values for DM included: solidarity (examine how society cares for the most } \\
\text { vulnerable); professional health care based on the ethics of solidarity and the principle of } \\
\text { beneficence; equality (fair distribution of resources); equity (when life and health are involved, } \\
\text { everyone is worth the same); utility (saving the highest number of lives); relational autonomy (the } \\
\text { autonomy of one affects the autonomy of others); reliability and reciprocity (based on the ethics of } \\
\text { solidarity, society gives privileges and respect to the professionals and expects them to care for the } \\
\text { infected patients). The DM must allocate scarce resources fairly, and the tool Swiss Influenza Pandemic } \\
\text { Plan is presented to aid in this task. }\end{array}$ \\
\hline (6) & $\begin{array}{l}2020 \\
\text { Israel }\end{array}$ & $\begin{array}{l}\text { Theoretical } \\
\text { reflection }\end{array}$ & $\begin{array}{l}\text { The DM, in the triage, must be based on the utility principle (helping people with a higher life } \\
\text { expectancy). When there is one resource for two people with different prognoses, it must be offered } \\
\text { and, if necessary, relocated, to the person with the better prognosis. When the utility principle is } \\
\text { unable to give support to DM, in the Jewish culture, it is possible to treat according to arrival in the } \\
\text { service, through draws, or simply by trusting the decisions made by the professionals. }\end{array}$ \\
\hline (8) & $\begin{array}{l}2020 \\
\text { USA }\end{array}$ & $\begin{array}{l}\text { Theoretical } \\
\text { reflection }\end{array}$ & $\begin{array}{l}\text { Advocates that, starting at admission, goals must be defined to attend the patient and for the use } \\
\text { of PPEs by health workers, especially during cardiorespiratory arrests, to guarantee their safety and } \\
\text { make it possible to carry out urgency attention faster. Hospitals must have an ethical team prepared } \\
\text { to guide professionals to make difficult decisions, minimizing anguish and the moral suffering } \\
\text { that are common in this moment. Protocols adopted must have clear criteria (years of life left and } \\
\text { comorbidities) for the cardiopulmonary resuscitation of infected patients. }\end{array}$ \\
\hline (9) & $\begin{array}{l}2020 \\
\text { USA }\end{array}$ & $\begin{array}{l}\text { Theoretical } \\
\text { reflection }\end{array}$ & $\begin{array}{l}\text { Describes COVID-19 implications for frontline nurses. Three ethical issues are discussed: 1) The } \\
\text { dilemma between the duty to care for the patient (beneficence) and dealing with the inadequacies } \\
\text { of the health system; 2) The allocation of scarce resources leads to inconsistent DM in a setting filled } \\
\text { with uncertainty; and 3) care is focused on the health needs of society. About DM for the allocation } \\
\text { of resources, directives and algorithms need to be created by specialists to give support to direct } \\
\text { assistance professionals. The relocation of resources must happen when there is one resource and } \\
\text { two patients with different prognosis (the one who is more likely to recover will receive the resource). } \\
\text { Nurses suffer with the ambiguity and the inability to do what would be morally correct, in addition } \\
\text { to the uncertainty about whether the decision made was the most adequate. Specialists that can be } \\
\text { consulted about clinical ethics can help minimize the suffering. }\end{array}$ \\
\hline (10) & $\begin{array}{l}2020 \\
\text { Italy }\end{array}$ & $\begin{array}{l}\text { Reflection } \\
\text { (opinion of } \\
\text { authorities) }\end{array}$ & $\begin{array}{l}\text { Defends that health institutions should have ethics specialists for difficult DM. From this perspective, } \\
\text { the SIAARTI created recommendations to aid physicians making decisions about the admission of } \\
\text { COVID-19 patients in the ICU. }\end{array}$ \\
\hline (11) & $\begin{array}{c}2020 \\
\text { Belgium }\end{array}$ & Reflection & $\begin{array}{l}\text { Decisions about the admission into ICUs must prioritize patients that, according to the physician, } \\
\text { have a good prognosis for recovery and a good quality of life. When resources are scarce, the } \\
\text { distributive justice must be applied to DM (resources must be distributed to those who are more } \\
\text { likely to benefit from them). During triage, the age, degree of fragility, and the preference of patients } \\
\text { must be considered. The study explains that it is justifiable to relocate a ventilator or a bed from } \\
\text { a patient with a bad prognosis to another with a better prognosis. Health services must have an } \\
\text { Ethics Committee or a leader that is available } 24 / 7 \text { in the ICU, to be consulted by professionals in the } \\
\text { case of difficult decisions. The study presents the Sequential Organ Failure Assessment Score to help } \\
\text { professionals make difficult decisions. }\end{array}$ \\
\hline (13) & $\begin{array}{c}2020 \\
\text { Canada }\end{array}$ & $\begin{array}{l}\text { Theoretical } \\
\text { reflection } \\
\text { (consensus } \\
\text { from specialists) }\end{array}$ & $\begin{array}{l}\text { Professionals, patients, and patient relatives must make decisions together, based on the following } \\
\text { principles: minimizing damage (non-maleficence/beneficence), distribute justice (equity), respect } \\
\text { and autonomy, proportionality, reciprocity, flexibility, and process justice. Solidarity is above } \\
\text { individual autonomy. }\end{array}$ \\
\hline
\end{tabular}


Chart 2 (concluded)

\begin{tabular}{|c|c|c|c|}
\hline Reference & $\begin{array}{c}\text { Year } \\
\text { Country }\end{array}$ & $\begin{array}{l}\text { Design } \\
\text { mento }\end{array}$ & Main results \\
\hline (14) & $\begin{array}{l}2020 \\
\text { Italy }\end{array}$ & $\begin{array}{l}\text { Theoretical } \\
\text { reflection } \\
\text { (opinion of } \\
\text { authorities) }\end{array}$ & $\begin{array}{l}\text { Addresses clinical criteria (severity of the disease, presence and importance of comorbidities, fragility, } \\
\text { organ failures and the stage of these failures, age of the patient, and cognitive and functional levels of } \\
\text { autonomy) and ethical criteria (beneficence, non-maleficence, autonomy, and distributive justice) to } \\
\text { guide the DM about the admission of patients with COVID-19 into the ICU. Distributive justice is not only } \\
\text { the right of the patient to have access to the treatments available; it also refers to the correct distribution } \\
\text { of the resources available (public ethics). The distributive justice is complemented by proportionality, } \\
\text { adaptation of care, equity, equality, and usefulness (allocating resources to provide the maximum benefit } \\
\text { at the lowest price). Considering the above, the Italian Society of Anesthesia, Analgesia, Reanimation and } \\
\text { Intensive Care (SIAARTI) created recommendations to give ethical support to the DM of professionals who } \\
\text { work in the front lines of the struggle against COVID-19. This document states that as many people and } \\
\text { as many years of life as possible should be saved. The hospitals need an independent organ formed by } \\
\text { specialists, who follow clear and transparent criteria, to give support to DM. }\end{array}$ \\
\hline (15) & $\begin{array}{l}2020 \\
\text { USA }\end{array}$ & $\begin{array}{c}\text { Reflection } \\
\text { (recommendation } \\
\text { from specialists) }\end{array}$ & $\begin{array}{l}\text { Presents recommendations to confront and solve some ethical challenges that emerged in the pandemic: } \\
\text { 1) Can the professional choose whether to provide care to COVID-19 patients? The recommendation } \\
\text { is that the care should be provided if the PPEs are adequate; } 2 \text { ) How should the allocation of scarce } \\
\text { resources, such as ICU beds, ventilators, and certain medications be done? The recommendation is that } \\
\text { systematic and transparent protocols should be adopted to help professionals in DM. }\end{array}$ \\
\hline (16) & $\begin{array}{l}2020 \\
\text { USA }\end{array}$ & $\begin{array}{l}\text { Theoretical } \\
\text { reflection }\end{array}$ & $\begin{array}{l}\text { Although they can be adopted during a pandemic, bioethical (autonomy, beneficence, non-maleficence, } \\
\text { and justice) and ethical values (maximizing the benefit from resources available, treating people with } \\
\text { equality, recognizing the instrumental value of professionals and prioritizing those in worse situations), } \\
\text { their application changes as the focus of health care becomes the collective. These principles must be } \\
\text { considered in DM. Professionals who work in the struggle against the coronavirus are instrumental to } \\
\text { society, and, therefore, must have priority when it comes to the allocation of resources when they fall ill. A } \\
\text { clinical triage team is a valuable resource to aid professionals in difficult DM. }\end{array}$ \\
\hline (21) & $\begin{array}{l}2020 \\
\text { Norway, } \\
\text { Israel, } \\
\text { Germany, } \\
\text { the United } \\
\text { Kingdom } \\
\text { France } \\
\text { and the } \\
\text { Netherlands }\end{array}$ & $\begin{array}{c}\text { Reflection } \\
\text { (consensus from } \\
\text { specialists) }\end{array}$ & $\begin{array}{l}\text { Discusses a change in the criteria for the triage of patients during the pandemic, which classifies them in } \\
\text { three stages: stage } 1 \text { (good) - there are resources available and the DM is based on good evidence; stage } \\
2 \text { (bad) - the demand grows and some resources are lacking; stage } 3 \text { (terrible) - the lack of resources is } \\
\text { severe. In the good stage, clinical prioritization can take place and DM can happen as usual, without the } \\
\text { need for intensive care and prognoses. In the bad stage, the professional may not admit patients with } \\
\text { doubtful prognoses. In the terrible stage, the usual medical triage and the establishment of priorities } \\
\text { may not be enough to diminish the influx, and there may not be enough ICU beds. In this stage, different } \\
\text { criteria must be applied using a utilitarian approach for the triage. The article also deals with the ethical } \\
\text { dilemma faced by professionals when they need to decide whether or not to admit elderly patients } \\
\text { (above } 80 \text { years old) in the ICU and have to deal with the social consequences of the decision made. }\end{array}$ \\
\hline (22) & $\begin{array}{l}2020 \\
\text { Spain }\end{array}$ & $\begin{array}{c}\text { Reflection } \\
\text { (consensus from } \\
\text { specialists) }\end{array}$ & $\begin{array}{l}\text { The ethics group Spanish Society of Intensive, Critical, and Coronary Care (SEMICYUC) and specialists } \\
\text { in the field of bioethics, geriatrics, and palliative care developed a document with guidance } \\
\text { for professionals regarding DM and the allocation of resources. This document considers, in its } \\
\text { structure, the availability of resources and alternatives (the optimization of personal, structural, and } \\
\text { material resources, the creation of specialist committees and contingency plans, among others); the } \\
\text { characteristics and the state of health of the patient (age, degree of fragility, preferences, values, and } \\
\text { adequate palliative care, in cases where the development is bad); and the DM guided by the ethics of } \\
\text { the decisions (triage based on the principles of distributive justice and proportionality, shared DM). }\end{array}$ \\
\hline (23) & $\begin{array}{l}2020 \\
\text { USA }\end{array}$ & $\begin{array}{l}\text { Theoretical } \\
\text { reflection }\end{array}$ & $\begin{array}{l}\text { Presents bioethics principles (beneficence; respect to autonomy) to DM during the pandemic. To allocate } \\
\text { resources, professionals must base their decisions on the principles of justice, clinical prognosis, and } \\
\text { on the duration of a need. It addresses the right of the patient to refuse treatment and the need for } \\
\text { professionals to communicate clearly and compassionately. The best possible care must be offered to the } \\
\text { patient with coronavirus, including palliative support, mental health care, and spiritual assistance. }\end{array}$ \\
\hline (24) & $\begin{array}{c}2020 \\
\text { United } \\
\text { Kingdom }\end{array}$ & $\begin{array}{l}\text { Theoretical } \\
\text { reflection } \\
\text { (consensus from } \\
\text { specialists) }\end{array}$ & $\begin{array}{l}\text { It addresses DM challenges in patients with cognitive disabilities and provides guidance according } \\
\text { with the Mental Capacity Act, which follows the principle of utilitarianism. }\end{array}$ \\
\hline (25) & $\begin{array}{l}2020 \\
\text { USA }\end{array}$ & $\begin{array}{l}\text { Theoretical } \\
\text { reflection } \\
\text { (recommendations } \\
\text { from specialists) }\end{array}$ & $\begin{array}{l}\text { The DM about triage, allocation and relocation of resources must be guided by ethical principles and } \\
\text { values: autonomy (in the pandemic, the priority is to maximize the number of lives and years saved, not } \\
\text { individual autonomy); beneficence/non-maleficence (workers cannot impose treatments on the patient); } \\
\text { justice (patients have equal access to resources, which must be allocated fairly); fairness (the priority } \\
\text { should be to allocate resources to younger people, who are more likely to be cured and live longer); } \\
\text { instrumental value (health professionals have priority in the access to resources, since, once cured, } \\
\text { they can help saving lives). During the pandemic, there must be a team of triage to help professionals } \\
\text { in difficult DM, helping to relief their moral suffering and to provide protection. Criteria to allocate and } \\
\text { relocate resources must be transparent. Professionals must provide the best attention possible, adopting } \\
\text { transparent and clear communication, respecting the autonomy of the patient (which is below the } \\
\text { greater objective of protecting more lives) and acting based on an utilitarian approach. }\end{array}$ \\
\hline (26) & $\begin{array}{l}2020 \\
\text { Spain }\end{array}$ & $\begin{array}{l}\text { Descriptive with } \\
\text { a qualitative } \\
\text { approach }\end{array}$ & $\begin{array}{l}\text { Presents clinical criteria to guide the professional DM in the triage of ICU patients, by calculating } \\
\text { the base functional and cognitive index, measuring the severity of the disease, the possibility of } \\
\text { a reversal, and the potential for recovery after treatment. It claims that each hospital must have a } \\
\text { triage committee with members with experience in treating people with COVID-19 and members of } \\
\text { the Institutional Health Ethics Committee to give support to the DM professionals. }\end{array}$ \\
\hline
\end{tabular}




\section{DISCUSSION}

From the articles analyzed, $12^{(2,4-6,9,11,13-14,16,23-25)}$ discussed ethical principles and values for the DM of professionals during this pandemic. "Principles", here, are understood as the starting point and the foundation of any process of being, of having a responsibility, and/or of knowing. Values mean any contribution for a life which is made according to reason, in accordance with nature, or which is deserving to be chosen ${ }^{(27)}$.

The essential bioethics principles (autonomy, beneficence, nonmaleficence, and justice) were the most mentioned ${ }^{(4,13-14,16,23-25)}$. Individual autonomy is related to self-determination or self-governance, to the power of deciding about oneself; beneficence means acting in the best interest of others; non-maleficence is the obligation of not prejudicing others and acting to avoid damage; and justice relates to the coherent and adequate distribution of social duties and benefits ${ }^{(28)}$, it means treating others fairly, impartially, and equally ${ }^{(16,28)}$.

During the attention to the person with COVID-19, the making of decisions related to the treatments adopted must go through the patient, who must agree, as the principle of autonomy advocates $^{(28)}$; this must be done in respect to the fact that all persons are capable of self-determination, as moral agents of infinite value. Therefore, physicians and other health professionals cannot retain or remove, unilaterally, a treatment that is clinically approved or indicated without the consent of the patient or of someone who can speak for the patient. Considering this reasoning, they have the duty of caring for the patient to improve their health and wellbeing and avoid doing harm, according with the precept of non-maleficence as described in a NorthAmerican study ${ }^{(25)}$.

In the setting of a crisis, the principle of autonomy is no longer focused on the individual and changes its focus towards what is beneficial to society (which is also known as "ethics of solidarity"). As a result, the decisions made by all professionals must consider social wellbeing, as show studies from Canada ${ }^{(13)}$ and the United States $^{(9,16)}$. One of the ways to prioritize the collective is to isolate suspected cases for the good of the population, that is, showing commitment to beneficence ${ }^{(4)}$. Furthermore, measures to encourage hand hygiene, respiratory etiquette, and the use of home-made facial masks, in addition to continuous social-distancing measures, were implemented in many countries, to a greater or lesser extent. Their results, probably, depend on socioeconomic and cultural aspects, on the characteristics of political and health systems, and on the operational procedures for their implementation ${ }^{(3)}$.

The preservation and effectiveness of these measures depend on the establishment of policies of social protection and for the support of vulnerable people ${ }^{(3)}$. This idea finds support on a study from Nepal which, in accordance with the principle of non-maleficence, states that the poor and marginalized, as well as people being treated for comorbidities, need social mechanisms that can aid them, since they are the ones who suffer the most with restrictive measures. Also, the professionals must pay close attention to these groups during $\mathrm{DM}^{(4)}$. Elders are one of the vulnerable groups, which makes the decision to admit them into ICUs an ethical dilemma ${ }^{(21)}$, since they are the population affected the most by COVID-19 and who is the most likely to die after hospitalization ${ }^{(29)}$.

Reflecting on this issue in regard to the elderly population, some problems that involve the DM by the health professionals should be highlighted. One of the most commonly mentioned ethical issues related to health involves deciding between offering resources (mechanical ventilation, beds in the ICU) to elderly people (80 years old or older) in a setting in which these resources are scarce, or to use them to attend to the needs of those infected by COVID-19. In this regard, an ethical specialist recommends prioritizing the younger, who are more likely to survive and live longer after the disease, while providing adequate palliative care to those who renounced the use of any specific resource, to provide them with a dignified death, assistance, and guarantee the least possible suffering ${ }^{(30)}$.

Although the authors of the North-American ${ }^{(25)}$ study corroborate the perception of this specialist, others believe this view to be controversial and discriminatory. They disagree, claiming the criteria of age alone is insufficient to make this decision, since not all elders are diseased and not all young people are healthy ${ }^{(11)}$. Therefore, this criteria cannot be considered alone, and many others should be taken into account, such as: years of life to be lived, presence and extent of comorbidities ${ }^{(8,14)}$, degree of fragility ${ }^{(14)}$, expectancy of recovery with good quality of life ${ }^{(11)}$, characteristics and state of health ${ }^{(22)}$, calculation of the base functional and cognitive levels, measurement of the severity of the disease, possibility of recuperation, and potential to recover after treatment ${ }^{(26)}$.

Regarding who receives priority in care, that is, the triage, whether it takes place in the admission, allocation, or relocation of resources, the results highlighted the predominance of the principle of utilitarianism in DM. According to this principle, a moral decision is only adequate when it brings the best results for the highest number of people. The DM must be based on helping those who have a higher life expectancy, and resources should be allocated to patients who are more likely to survive, to be cured, and have the perspective to have a reasonable quality of life $(2,4,6,11,25)$.

A British study stated that the utilitarian principle was the base for the creation of the Mental Capacity Act, an instrument formed by variables that indicate how and when professionals can make decisions for the good of their patients with cognitive disabilities ${ }^{(24)}$. This helps making the best decision possible, focusing on providing holistic and integral health care. An American study follows a similar path with regard to attending the patient with coronavirus, stating that the best possible care should be provided to them, including palliative care, mental health care, and spiritual assistance ${ }^{(23)}$.

An example of the adoption of the utilitarian principle is expressed when two patients with distinct prognosis need the same resource, but it can only be provided to one of them. In this case, the resource is offered to the person who has a better prognosis, even if this means that the resource should be relocated $(2,6,9)$. During this process, the DM should also consider the distributive justice principle, that is, resources must be allocated or relocated to those who are likely to reap more benefits and to survive ${ }^{(11,22)}$. Health professionals, in turn, must remain neutral and impartial ${ }^{(2)}$.

Even when they are aware of this reality, professionals in the front lines need to deal with painful and traumatic choices, and as a result, feel impotent, guilty, anguished, and suffer morally ${ }^{(6,9)}$. This setting may also get worse when there are insufficient human and material resources and inadequate working conditions $^{(31)}$. Some authors believe that it is necessary to emphasize to professionals that, in situations of crisis in health care, such as experiences during the COVID-19 pandemic, the circumstances 
are not under their personal control; even if they offer all the lifesupport treatments there are, some patients will not survive ${ }^{(9,25)}$.

From this perspective, this pandemic came like an avalanche. It was an unprecedented situation in modern history, and it generated, in these professionals, suffering, fear, dilemmas, anxiety, and uncertainties in daily work. These workers have to deal with the challenge of making ethically safe and reasonable decisions when confronted with the scarcity of resources and the lack of knowledge about the exact way in which the virus propagates, not to mention the lack of effective treatment.

In the beginning of the pandemic, mistakes regarding triage, admission, and the allocation of resources were made ${ }^{(8,26)}$. In a setting where sanitary resources are overloaded, as is the case during COVID-19, professionals must deal with situations that require complex decisions, and, on occasion, they must decide who will not receive the ideal treatment. As a result, they feel anguish and suffering, especially in urgent situations, which require fast actions with no reflection on the circumstances ${ }^{(12)}$.

North-American studies have reported this issue as they described that some American institutions, when there was no PPE, advocated orders not to reanimate or to delay the start of thoracic compressions, due to worries about the release of aerosols ${ }^{(8,15)}$. SARS-CoV-2 patients must be attended with caution to guarantee the safety of the professionals ${ }^{(8)}$, who, generally, become emotionally exhausted ${ }^{(16)}$. Providing safety to these workers is the role of the health institutions, who must provide both the adequate PPEs in a sufficient amount and training on their correct and rational use. The professionals have the social responsibility to use PPEs in situations where they risk exposure.

In an attempt to minimize the possibility of health professionals getting mentally ill, studies recommend, as alternatives, the creation of Triage and Health Ethics Committees, as well as the formation of teams by professionals who have experience in dealing with COVID-19 and ethical issues ${ }^{(8,16,26)}$. These can elaborate criteria for the admission and allocation of resources, guiding the professionals in the front line in the making of hard decisions. The criteria established must be structured in protocols or algorithms, and must include clear and transparent information for professionals, patients, and patient relatives ${ }^{(8,14,16)}$. It is worth highlighting that, even with carefully developed protocols there will always be uncertainties $^{(9,11)}$, and one must learn to deal with them.

The need to allocate supplies, equipment, beds, medication and human resources in a pandemic can generate ethical and moral conflicts for decision makers, leading to physical and mental disease $^{(32)}$. As a result, there must be a shared structure for ethical DM based on a dialogue between health professionals and society. Still, the decisions made must be robust (well thought-out), reasonable (based on evidence and relevant factors), transparent (the decision-making process must be clear and open) and fair (the resources must be distributed equally) ${ }^{(13)}$.

There are shortcomings in the DM about the best allocation of equipment, which shows that professionals are not prepared for it. However, this decision should not be based on pandemic control measures, but on preestablished criteria to better direct the resources available in order to attend to a specific populational reality ${ }^{(33)}$. In an attempt to deal with this shortcoming, protocols, manuals and instruments are adopted to guide the DM when it comes to resource allocation; however, these are often unable to prevent conflict and, often, lead to interventions that are not pertinent or, in some cases, even unfair ${ }^{(12)}$.

The studies analyzed, in order to guide the health practices adopted in this new reality, suggested protocols and orientations elaborated by ethical committees, such as the a document which included the position and recommendations from the SEMICYUC, in Spain, based on solid criteria, fundamental ethical principles and the equal and fair provision of service ${ }^{(22)}$; the Blue Code, from the United States $^{(8)}$; the recommendations from the SIAARTI ${ }^{(10,14)}$; the clinical directives for DM in the response of COVID-19, elaborated by the National Institute of Health from the United Kingdom ${ }^{(6)}$; and the demands from the Mental Capacity Act, to guide DM when the patient, due to cognitive disability, cannot participate in the decision making process ${ }^{(24)}$.

It should also be mentioned that the protocols, algorithms, and guidance are not always enough to subsidize DM. However, fundamental bioethical principles should guide any decision in health ${ }^{(12)}$. Professionals also should resort to their religious beliefs, motivations and values, both as people and professionals ${ }^{(2)}$, and must guide themselves according to the decisions of the local authority that regulates their profession, also considering their Professional Code of Ethics (PCE).

Solidarity, equity, utilitarianism, relational autonomy, reliability, and reciprocity, adopted by the health professionals during COVID-19, are the marks that guide a humane, dignified, and integral action when difficult decisions must be made. This includes deciding who will receive potentially curative treatment, knowing that those who do not may not survive ${ }^{(12)}$, and asking if the professionals can choose whether to provide care to COVID-19 patients, especially if the procedure to be performed puts their own safety at risk ${ }^{(9,13)}$. In summation, the process of DM is widely experienced by health professionals in their work routine as they struggle against the coronavirus; knowing how to make decisions makes a difference in this moment of uncertainty, since the choices made will guide attention, leading to the continuity or interruption of lives.

\section{Study limitations}

Although there have been other pandemics throughout history, this study, intentionally, only discussed the most recent one, caused by SARS-CoV-2. Furthermore, during the elaboration of this study, new works may have been published due to the fact that society and the scientific community need knowledge about COVID-19. However, instead of exhausting the topic, this work aims to raise questions for other investigations to be made, due to the relevance of the subject.

\section{Contributions for the field of nursing and health}

The results of this revision are relevant, but an article is too small to group the abundant knowledge on the issue of DM by health professionals who struggle against the coronavirus around the world. Although the nursing category is the largest health workforce in the world and DM is a competency of nurses, the studies analyzed showed that DM by nurses is seldom addressed. As a result, this work encourages the development of 
investigations that articulate this topic and nursing, to fill in this gap in knowledge, which still persists.

\section{FINAL CONSIDERATIONS}

This review found that DM has never been so as necessary as now, when demand is higher than supply. Resources are scarce, and professionals have accumulated stress and emotional burdens that prevent them from attending with efficiency, quality, ethics, and humanity a large number of people who were infected by COVID-19 and other diseases.

This article does not attempt to be a recipe for professionals, due to the fact that DM involves multiple factors. However, it provides many bases, presented in its results and discussion, that can aid them in this difficult and complex process, so they can make ethical and safe decisions.

To this end, to aid the DM during the pandemic, many alternatives can be adopted, including ethical principles such as utilitarianism; a fair and targeted allocation of resources; in addition to the creation of triage and health ethics committees, and of teams of professionals with experience confronting COVID-19 and dealing with ethical issues. The use of protocols or algorithms with clear and transparent information also contributes for this process, not to mention that professionals should resort to their own beliefs, motivations, and values, and follow the guidelines of the authorities that regulate their professions.
The COVID-19 pandemic asks health professionals to make hard decisions, which leads to moral suffering. They are advised to dialogue with other members in the health team about how to better deal with the ethical dilemmas and conflicts that appear in their daily work. Furthermore, health institutions should guarantee that workers have better working conditions. This includes the provision of adequate PPEs, training, psychological support, and the implantation of a committee of specialists, preferably ethics specialists, that can be consulted when there are difficult decisions to be made. Giving support to professionals is to recognize their instrumental value without letting their efforts go unnoticed, as they risk their own lives to save others.

The results of this revision are expected to encourage reflection about the DM of nursing professionals in dealing with COVID-19, aiding in their recognition of the ethical challenges they experience in their daily work and aiding in the resolution of these challenges through shared processes of decision making, based on evidence whenever possible.

\section{FUNDING}

Conselho Nacional de Desenvolvimento Científico e Tecnológico (the National Council of Scientific and Technological Development - CNPq) and the Coordenação de Aperfeiçoamento de Pessoal de Nível Superior (the Coordination for the Improvement of Higher Education Personnel - CAPES), for PhD scholarships.

\section{REFERENCES}

1. World Health Organization (WHO). Coronavirus disease (COVID-19) outbreak [Internet]. Geneva: World Health Organization; 2020[cited 2020 Jul 20]. Available from: https://www.who.int/emergencies/diseases/novel-coronavirus-2019

2. Iserson K. Healthcare ethics during a pandemic. West J Emerg Med. 2020;21(3):477-83. https://doi.org/10.5811/westjem.2020.4.47549

3. Aquino EML, Silveira IH, Pescarini JM, Souza-Filho JA, Rocha AS, Ferreira A, et al. Social distancing measures to control the COVID-19 pandemic: potential impacts and challenges in Brazil. Cienc Saude Colet. 2020;25(suppl 1):2423-46. https://doi. org/10.1590/1413-81232020256.1.10502020

4. Shah A, Aacharya RP. Combating COVID-19 pandemic in Nepal: ethical challenges in an outbreak. JNMA J Nepal Med Assoc. 2020;58(224):276-9. https://doi.org/10.31729/jnma.4959

5. Jeffrey DI. Relational ethical approaches to the COVID-19 pandemic. J Med Ethics. 2020;46:495-8. https://doi.org/10.1136/ medethics-2020-106264

6. Solnica A, Barski L, Jotkowitz A. Allocation of scarce resources during the COVID-19 pandemic: a jewish ethical perspective. J Med Ethics. 2020;46:444-6. https://doi.org/10.1136/medethics-2020-106242

7. Marquis BL, Huston CJ. Administração e liderança em enfermagem. 8a ed. Porto Alegre: Artmed; 2015.

8. Chan PS, Berg RA, Nadkarni VM. Code blue during the COVID-19 pandemic. Circ Cardiovasc Qual Outcomes. 2020;13(5):e006779. https:// doi.org/10.1161/circoutcomes.120.006779

9. Morley G, Grady C, Mccarthy J, Ulrich CM. Covid-19: ethical challenges for nurses. Hastings Cent Rep. 2020;50(3):35-9. https://doi. org/10.1002/hast.1110

10. Nicoli F, Gasparetto A. Italy in a time of emergency and scarce resources: the need for embedding ethical reflection in social and clinical settings. J Clin Ethics. [Internet]. 2020[cited 2020 July 27];31(1):92-4. Available from: https://pubmed.ncbi.nlm.nih.gov/32213700/

11. Vincent J-L, Creteur J. Ethical aspects of the COVID-19 crisis: how to deal with an overwhelming shortage of acute beds. Eur Heart J Acute Cardiovasc Care. 2020;9(3):248-52. https://doi.org/10.1177/2048872620922788

12. Sanches MA, Cunha TR, Siqueira SS, Siqueira JE. Perspectivas bioéticas sobre tomada de decisão em tempos de pandemia. Rev Bioet. 2020;28(3):410-7. https://doi.org/10.1590/1983-80422020283401

13. Virani A, Singh G, Bewick D, Chow C-M, Clarke B, Cowan S, et al. Guiding cardiac care during the COVID-19 pandemic: How ethics shapes our health system response. Can J Cardiol. 2020;36(8):1313-6. https://doi.org/10.1016/j.cjca.2020.06.002 
14. Romanò M. Fra cure intensive e cure palliative ai tempi di CoViD-19. Recenti Prog Med. 2020;111(4):223-30. doi: http://doi. org/10.1701/3347.33185

15. Kramer JB, Brown DE, Kopar PK. Ethics in the time of coronavirus: recommendations in the COVID-19 Pandemic. J Am Coll Surg. 2020;230(6):1114-8. https://doi.org/10.1016/j.jamcollsurg.2020.04.004

16. Rawlings $A, B$ Bandt L, Ferreres $A$, Asbun $H$, Shadduck P. Ethical considerations for allocation of scarce resources and alterations in surgical care during a pandemic. Surg Endosc. 2021;35(5)2217-22. https://doi.org/10.1007/s00464-020-07629-x

17. Paula CC, Padoin SSM, Galvão CM. Revisão integrativa como ferramenta para tomada de decisão na prática clínica. In: Lacerda MM, Costenaro RGS. Metodologias da pesquisa para a enfermagem e saúde: da teoria à prática. Porto Alegre: Moriá; 2016. p. 51-76.

18. Lockwood C, Munn Z, Porritt K. Qualitative research synthesis: methodological guidance for systematic reviewers utilizing metaaggregation. Int J Evid Based Healthc. 2015;13(3):179-87. https://doi.org/10.1097/XEB.0000000000000062

19. Melnyk BM, Fineout-Overholt E. Evidence based practice in nursing and healthcare: a guide to best practice. Philadelphia: Lippincot Williams \& Wilkins; 2005. Making the case for evidence based practice; p. 3-24.

20. Moher D, Liberati A, Tetzlaff J, Altman DG, The PRISMA Group (2009). Preferred Reporting Items for Systematic Reviews and Meta-Analyses: The PRISMA Statement. PLoS Med. 2009;(6):e1000097. doi: https://doi.org/10.1371/journal.pmed1000097

21. Flaatten $\mathrm{H}$. The good, the bad and the ugly: pandemic priority decisions and triage. J Med Ethics. 2020;0:1-3. https://doi.org/10.1136/ medethics-2020-106489

22. Rubio O, Estella A, Cabre L, Saralegui-Reta I, Martin MC, Zapata L, et al. Recomendaciones éticas para la toma de decisiones difíciles en las unidades de cuidados intensivos ante la situación excepcional de crisis por la pandemia por COVID-19: revisión rápida y consenso de expertos. Med Intensiva. 2020. https://doi.org/10.1016/j.medin.2020.04.006

23. DeBruin D, Leider JP. COVID-19: The shift from clinical to public health ethics. J Public Health Manag Pract. 2020;26(4):306-9. https://doi. org/10.1097/PHH.0000000000001204

24. Parsons JA, Johal HK. Best interests versus resource allocation: could COVID-19 cloud decision-making for the cognitively impaired? J Med Ethics. 2020;46:447-50. https://doi.org/10.1136/medethics-2020-106323

25. Kirkpatrick JN, Hull SC, Fedson S, Mullen B, Goodlin SJ. Scarce-Resource allocation and patient triage during the COVID-19 pandemic: JACC review topic of the week. J Am Coll Cardiol. 2020;76(1). https://doi.org/10.1016/j.jacc.2020.05.006

26. Herreros B, Gella P, Asua DR. Triage during the COVID-19 epidemic in Spain: better and worse ethical arguments. J Med Ethics. 2020;46:45558. https://doi.org/10.1136/medethics-2020-106352

27. Nocola A. Dicionário de Filosofia. 5. ed. rev. ampl. São Paulo (SP): Martins Fontes; 2007. 1026 p.

28. Koerich, MS, Machado RR, Costa E. Ética e bioética: para dar início à reflexão. Texto Contexto Enferm. 2005;14(1):106-10. https://doi. org/10.1590/S0104-07072005000100014

29. Fhon JRS, Silva LM, Leitón-Espinoza ZE, Matiello FB, Araújo JS, Rodrigues RAP. Atendimento hospitalar ao idoso com COVID-19. Rev LatinoAm Enfermagem. 2020;28(e3396):1-10. https://doi.org/10.1590/1518-8345.4649.3396

30. Miller FG. Why I Support Age-Related Rationing of Ventilators for Covid-19 Patients [Internet]. 2020 [cited 2020 Dec 29]. Available from: https://www.thehastingscenter.org/why-i-support-age-related-rationing-ofventilators-for-covid-19-patients/

31. Teixeira CFS, Soares CM, Souza EA, Lisboa ES. A saúde dos profissionais de saúde no enfrentamento da pandemia de Covid-19. Ciênc Saúde Coletiva. 2020;25(9):3465-74. https://doi.org/10.1590/1413-81232020259.19562020

32. Silva KR, Ribeiro RM, Roquete FF, Rodrigues CM, Lopes PT, Fernandes ML, et al. Narratives of health professionals relating to scarce resources in an urgency service. Int J Adv Engin Res Sci. 2019;6(6):66-73. https://doi.org/10.22161/ijaers.6.6.7

33. Koonin LM, Pillai S, Kahn EB, Moulia D, Patel A. Strategies to inform allocation of stockpiled ventilators to healthcare facilities during a pandemic. Health Security. 2020;18(2):1-6. https://doi.org/10.1089/hs.2020.0028 